\title{
Occurrence of polar seabirds at sea in relation to prey concentrations and oceanographic factors
}

\author{
GEORGE L. HUNT, JR.
}

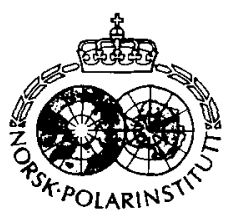

\begin{abstract}
Hunt, G. L., Jr. 1991: Occurrence of polar seabirds in relation to prey concentrations and oceanographic factors. Pp. 553-559 in Sakshaug. E., Hopkins. C. C. E. \& Øritsland, N. A. (eds.): Proceedings of the Pro Mare Symposium on Polar Marine Ecology. Trondhcim. 12-16 May 1990. Polar Research 10(2).

The distribution and abundance of breeding and foraging seabirds is usually a reflection of the availability of prey in the marine ecosystems on which the birds depend. At the scale of hundreds of $\mathrm{km}$, differences in marine communities may be reflected in variation in the species composition of resident seabirds. At small scales, environmental features such as fronts or ice can influence where birds will aggregate to forage. Features at which prey become concentrated near the surface are of particular importance to bird species dependent upon small planktonic organisms. Concentrations of foraging seabirds frequently indicate the presence of such features, or of areas of unusually high prey biomass. The absence of birds does not mean that concentrations of potential prey are absent. "Assembly rules," by which one might predict aspects of the marine environment that birds should use in selecting foraging areas are proposed.
\end{abstract}

George L. Hunt, Jr., Department of Ecology and Evolutionary Biology, University of California, Irvine, California 92717, USA.

\section{Introduction}

Interest in the role of seabirds in marine ecosystems has increased dramatically in the past decade. Recent papers have reviewed the oceanographic features which attract birds (e.g. Brown 1980), scales of interaction between birds and oceanographic environments (e.g. Hunt \& Schneider 1987; Hunt 1990), and the energetic role of marine birds (e.g. Croxall 1984, 1987). The ecology of marine birds in polar oceans has received particular attention, both because of increased interest in high latitude oceans, and because marine birds achieve some of their highest densities and greatest potential for ecological impact at higher latitudes (Hunt \& Nettleship 1988; Brown 1989; Ainley \& DeMaster 1990; Hunt 1991). In this contribution I briefly describe ecological factors that influence the atsea distribution of marine birds, and propose a framework for developing "assembly rules" for predicting where birds should forage.

\section{Ecological factors influencing at-sea distribution}

\section{Macro and meso scales (100s to 1000 s of $\mathrm{km}$ )}

Outside periods of migration when marine birds may cross large areas of relatively unproductive water (Ainley \& Boekelheide 1983), the at-sea distribution of marine birds is dependent on the availability of adequate stocks of appropriate prey. During the breeding season, the availability of nest sites places an additional constraint on both the distribution and abundance of marine birds. For instance, the lack of rocky cliffs along much of the low-lying High Arctic coastline results in the absence of bird species that might otherwise nest there (Brown 1989). In other Arctic regions, terrestrial ice and snow cover may exclude birds that could otherwise find nearby food resources adequate to support breeding. Similarly, in the Antarctic, the lack of continental coastal areas with suitable ice-free nest sites and the relatively small number of islands available to breeding birds in the subantarctic put constraints on the distribution and abundance of marine birds (Croxall 1984; Hunt \& Nettleship 1988). Nevertheless, given that colony sites are available, most evidence now suggests that it is the availability of prey in the vicinity of colonies that limits colony size (Furness \& Birkhead 1984; Birkhead \& Furness 1985) and reproductive performance (Gaston et al. 1983; Hunt et al. 1986). However, in some cases the availability of nest sites within colonies may influence the abundance of birds breeding at a site, and competition for nest sites is evident (Belopol'skii 1957; Williams 1974; Squibb \& Hunt 1983). 
Prey availability is a function of the geographical distribution of appropriate prey, the abundance of prey, and the accessibility of the prey as determined by local oceanographic conditions (e.g. ice cover, turbidity and physical processes that interact with prey behavior to cause concentration). At large scales, significant differences in prey community composition exist between water masses; at smaller scales, the major variation may be in prey biomass rather than in species composition (Haury et al. 1978). To the extent that marine birds prefer particular prey species or prey types, the species of marine birds present can be expected to vary between water masses that support different prey communities.

Evidence from both the Arctic and the Antarctic shows that bird species composition varies between water masses supporting different prey communities and trophic pathways. In the Bering Sea, the species composition of both nesting and foraging seabirds varies among the several water masses present (Hunt et al. 1981a, b; Schneider et al. 1986; Springer et al. 1987; Hunt \& Harrison 1990). Similarly, variation in marine bird communities among water masses supporting different prey communities is found in the Greenland Sea/Barents Sea region (Mehlum 1989). In the Antarctic, Ainley \& Boekelheide (1983), SCAR (1985) and Veit (1988) have found latitudinal variation in marine bird species assemblages that reflect a combination of physical features (such as ice cover and wind velocity) and prey types used by the birds. In the Bransfield Strait and Southern Drake Passage, Hunt et al. (1990b) found that marine bird assemblages varied between water masses. Some of the variation observed could be explained by likely differences in prey distributions, whereas in other cases, the location of nearby colonies appeared to be an important factor. However, explanations for differences between bird species in foraging location based on colony location still require understanding of why colonies have been located where they are. In many cases, the selection of colony sites must have been influenced by regional or local prey distributions.

\section{Coarse and fine scales (10s of $m 10100 \mathrm{~km}$ )}

Marine birds aggregate and forage at a wide variety of hydrographic features that bring prey into the upper water column or that concentrate prey.
If concentration of prey is to occur, there is in many cases a requirement for a behavioral response by the prey to a gradient opposite to the physical forcing. For instance, vertically migrating euphausiids that seek low light levels during the day will be concentrated in an upwelling when they swim downward against the current in an attempt to remain at depth (Simard et al. 1986). Likewise, neuston is concentrated at a convergence when the buoyancy of the organisms acts against the downwelling current (Stavn 1971; Pingree et al. 1974).

Oceanic fronts have long been regarded as areas of enhanced biomass (Uda 1938; Pingree et al. 1974), either because of nutrient regeneration and increased primary production (lverson et al. 1979) or because of physical mechanisms that concentrate organisms (Schneider 1991). In the Bering Sea, marine birds are frequently present in elevated numbers at fronts (Schneider 1982; Kinder et al. 1983; Hunt \& Harrison 1990; Schneider et al. 1990). In the Southern Hemisphere, Veit (1985) found that Long-tailed Jaegers (Stercorarius longicaudus) were aggregated at a front associated with the Falkland Current. Similarly, Abrams \& Lutjeharms (1988) identified frontal zones of the Agulhas Current Retroflection region south of the southern tip of Africa as an important source of variance in seabird densities. However, when Schneider et al. (1987) examined the frequency of occurrence of birds at the interdomain fronts in the southeastern Bering Sea, elevated numbers of birds at frontal regions were found no more often than would be expected by chance. When they examined the situations under which aggregations of birds did occur at fronts, they found that the probability of finding birds at a front was a function of the strength of the front. At a larger scale, Ainley \& Boekelheide (1983) and Ainley et al. (1984) failed to find significant increases in avian biomass at the Antarctic Convergence, either in the southwestern Pacific Ocean or in Drake Passage. However, in the African sector of the Antarctic, Griffiths et al. (1982) did find elevated numbers of birds at the convergence.

In polar waters, the marginal ice zone forms a frontal area of major importance to both physical and biological processes (Buckley et al. 1979; Stirling 1980; Dunbar 1981; Niebauer \& Alexander 1985; Smith \& Nelson 1986; Smith 1987). The presence of heavy ice cover excludes birds early in the spring from areas that they may later 
occupy once the ice is gone (eg. Bering Sea, Shuntov 1961; Divoky 1979). Where the ice edge is well-defined, it has in some cases been shown to be an area where foraging birds concentrate (Bradstreet 1979, 1982, 1988; Divoky 1979; Ainley et al. 1984; Fraser \& Ainley 1986), whereas in other areas, the ice edge appears to be of less importance for attracting aggregations of foraging birds (Veit 1988; Veit \& Hunt 1991; see Hunt 1990 , 1991, for reviews). Some of these differences in results may be caused by the patchy distribution of birds along the ice edge (Bradstreet 1982; Bakken \& Hunt unpub.) and the usual small sample of ice edge crossings in any one study. However, the differences between regions in bird occupation of the ice edge may also reflect an underlying difference in the trophic webs available to support marine birds. In the Arctic, multiyear ice and ice over shallow water support an amphipod fauna richer in species and biomass than that found under first year ice, especially first year ice over deep water (Gulliksen \& Lønne $1989,1991)$. Where the rich under-ice fauna is lacking, there may be insufficient ice-related fauna to support birds. Under these circumstances avian prey consists of primarily free-swimming pelagic forms and the birds may gain little by concentration near the ice edge (Lønne pers. comm.). Seaward of the ice edge, the marginal ice zone contains a region that is stratified by the presence of a layer of fresh meltwater at the surface (Niebauer \& Alexander 1985; Smith 1987). This "outer" region of the marginal ice zone is the site of intense algal blooms and, at least in some regions, high secondary productivity (Alexander \& Niebauer 1981; Smith 1987). Although concentrations of birds in this region may not be as dense as they are along the margin of the ice, overall numbers may be much greater due to the large area involved. At present we lack the data to determine the relative importance of the ice edge versus the outer meltwater zone, but it is likely that the latter will prove to be the more important, particularly in regions where the icerelated fauna is not well-developed. In both the ice edge and the meltwater zones, the key to avian use is the presence of trophic linkages between the primary production and the avian consumers. When these elements are lacking (e.g. the Middle Domain of the southeastern Bering Sea Shelf, Coyle \& Cooney 1988), there is little reason to expect that ice cover will enhance trophic flux to birds. When secondary production is high, birds may concentrate at the ice edge, in the outer meltwater zone, or at the frontal areas where the pycnocline approaches the surface at the outer extreme of the meltwater zone (Fraser \& Ainley 1986).

At sites of upwelling driven by strong tides encountering underwater reefs, concentrations of birds are correlated with concentrations of prey upwelled into surface waters (Vermeer et al. 1987; Brown \& Gaskin 1988). These events are often at a scale of $<5 \mathrm{~km}$ and show temporal fluctuations both at the scale of tidal cycles, and at a seasonal scale. The shorter temporal scale is a result of an asymmetry in the upwelling of prey that depends on the direction of tidal flow; the seasonal variation reflects migratory patterns of the birds, and, in the case of Vermeer et al., seasonal variations in the abundance of various plankton species.

Langmuir circulation cells are another finescale physical phenomenon that has the potential to concentrate prey at the water's surface (Owen 1966; Barstow 1983). Although their locations are not predictable in time or space, whenever there is sufficient wind these cells form, and their zones of convergence are easily seen from afar. Brown (1980) observed numerous birds off Peru feeding in convergences associated with Langmuir cells. In the Bering Sea, Hamner \& Schneider (1986) found jellyfish concentrated in Langmuir cells, but there are no reports of jellyfish-eating birds taking advantage of these concentrations.

In contrast to physical factors that increase the availability of prey in predictable locations, biological interactions between prey organisms or between prey and predators that result in enhanced prey availability to seabirds are often not predictable in location, at least at small scales. For instance, in the Arctic, Ivory Gulls (Pagophila eburnea) occasionally scavenge the remains of Polar Bear (Urus maritimus) prey (Blomqvis \& Elander 1981). The mesoscale area in which bears are present is highly predictable on a seasonal basis, but exactly where and when a bear will make a kill is not easily predicted. Likewise, in the Chirikov Basin in the northern Bering Sea, several species of birds forage on particles of prey released when Grey Whales (Eschrichtius robustus) surface to breathe and expel mud and water through their baleen (Harrison 1979; Obst \& Hunt 1990). The general foraging area of the whales is determined by the distribution of infaunal benthic amphipods (Nerini 1984) and that 
distribution could be learned by birds. However, the underwater movements of the whales make it very difficult to predict exactly when and where a whale will surface. Similar arguments could be made for areas where bird species benefit from the activity of predatory fish which drive bait fish or invertebrates to the surface. An interesting exception may be the system studied by Safina $\&$ Burger $(1985,1988)$ in which predatory bluefish (Pomatomus salatrix) drive small bait fish to the surface where common terns (Sterna hirundo) can then prey upon them. The locations where the bluefish attack the bait fish are apparently fixed in time and space by tidal currents near passages and inlets in the barrier islands off the mid-Atlantic coast of the United States. Under these circumstances, the activities of predatory fish in increasing prey availability may be predictable in time and space (see Johannes 1981 for a tropical example).

The social behavior and migratory behavior of prey influence their availability to birds. Whereas vertical migrations may provide a strongly predictable diurnal variation in prey availability, swarming behavior, at least at the smaller spatial scales, decreases the predictability of encountering prey. In the Antarctic, Antarctic krill (Euphausia superba) migrate toward the sea surface at night, where they are often found spread out in a diffuse layer (Everson 1983). During the day, this layer descends and coalesces into separate, distinct aggregations; these aggregations have a spatial distribution that is often indistinguishable from random (Miller \& Hampton 1989). Aggregations of krill under these circumstances are presumably difficult to find and crop, unless they were first encountered while near the surface and were subsequently followed to depth by predators.

Concentrations of birds frequently correspond to concentrations of their prey at fine scales (see Hunt 1990 for review). Obst (1985), working in the Antarctic, was able to show that avian density and biomass were higher in waters where krill were present, and that for some species of birds the probability that krill was present increased when larger numbers of birds were present. Obst was not able to predict bird abundance on the basis of krill abundance or the depth at which krill were present. Heinemann et al. (1989), working near where Obst had worked, found only two of seven bird species with statistically significant correlations with krill at the scale of nautical miles. The two largest aggregations of foraging birds seen were associated with krill, but overall, many patches of krill had no birds in attendance. Similarly, in the northern Bering Sea, Least Auklets (Aethia pusilla) forage on copepods and other small zooplankton in stratified waters 15$55 \mathrm{~km}$ from their colonies (Hunt et al. 1990a). Statistically significant rank correlations between predator and prey abundance at and above the thermocline were found at the scale of 1-2 nautical miles on 3 of 5 transects at St. Lawrence Island, but many large zooplankton patches lacked attending aggregations of auklets. The lack of birds does not indicate the lack of prey concentrations.

\section{Assembly rules for foraging birds}

Based on this very brief review of some aspects of the foraging ecology of marine birds and situations that increase the availability of prey, I would like to suggest some "assembly rules" for the choice of foraging area for marine birds. The formal development of these "rules" is left for a subsequent contribution. The data necessary for testing the "rules" have in most cases yet to be gathered. However, it is necessary to seek order in the multiplicity of our observations and to develop hypotheses whereby we may predict how birds should deploy their foraging effort, and hence better understand their connection to the sea.

Rule 1. - Birds seeking colony sites should choose areas on the basis of large scale (mesoscale and greater) characteristics of their foraging arena; for individual foraging trips, small scale events are likely to be better predictors of prey availability.

Rationale: Prey types will be distributed in relation to mesoscale or larger water masses and hence mesoscale water masses will provide the proper habitats in which to seek appropriate prey species or types. These large scale distributions will set the limits to where successful nesting is possible. Embedded in, or along, the fringes of these watermasses, smaller scale phenomena will result in concentrations of prey that can be profitably exploited. When foraging, seabirds would be expected to seek these concentrations, and we find intradomain variance is often greater than interdomain variance in bird abundance. Foraging events are inherently at small scales (tens to hundreds of meters). 
Rule 2. - At any given scale, foraging birds should seek out the strongest property and flow gradients as foraging areas.

Rationale: Strong flow and property gradients are more likely to be detected by and to influence prey organisms than weak gradients. Strong upwellings have a greater probability of transporting organisms to the surface against the attempts of prey to remain at depth. In the Bering Sea, the results of Schneider et al. (1987) indicate the importance of frontal strength; observations at tidally driven upwellings invariably show the importance of current velocity (Vermeer et al. 1987). Even in the vertical dimension, there is limited evidence that the number of foraging birds is correlated with strength of the thermocline (pycnocline) (Hunt et al. 1990a).

Rule 3. - Predictability of resource location and availability is greater when resource concentrations are physically forced and topographically fixed than when they are primarily the result of behavioral interactions.

Rationale: As discussed above, when the availability of prey is determined by the actions of other predators or social interactions among prey organisms, the locations of particular patches of prey are not easily predicted at the smallest scales, even though the areas (at a mesoscale level) where prey patches will occur can be predicted. Breeding birds, particularly those with energetically expensive modes of travel, should prefer to use topographically fixed concentrations of prey, where available (Schneider et al. 1986, 1990). Species with highly efficient fight or species not tied to a breeding colony may be more effective at taking advantage of the less predictable and possibly more ephemeral behaviorally-forced prey aggregations (e.g. Procellariformes in the Southern Hemisphere, Hunt \& Nettleship 1988). At grey whale mud plumes, the most common birds are Black-legged Kittiwakes (Rissa tridactyla) and Northern Fulmars (Fulmarus glacialis), both of which have relatively low wing-loading, and migratory phalaropes (Obst \& Hunt 1990). In comparison, alcids have high wing-loading, and few alcids, with the exception of the occasional murre, sought food from surfacing grey whales.

Other rules have been suggested, and still others await formulation. At the global scale, Ainley (1977) proposed the "rule" that pursuit divers are most often found in turbid, high latitude waters, while plunge diving species of birds are most often found in clear, tropical waters. This generality has held up at smaller scales as well (Briggs et al. 1988), despite the finding of some exceptions (Hunt \& Schneider 1987; Haney \& Stone 1988; Haney 1990). Wind and weather patterns may also be used by birds in predictable ways, but we are only just beginning to examine the impact of these variables on foraging behavior. The importance of wind energy in shaping global patterns of bird distribution is well-accepted (Harrington et al. 1972; Ainley \& Boekelheide 1983; Blomqvist \& Peterz 1984). The observations of Manikowski (1975) and more recently of Jouventin \& Weimershirch (1990) suggest that foraging birds may adjust their movements to take advantage of the prevailing wind. Just as hydrographic processes have been shown to influence avian foraging, it is likely that atmospheric interactions are also important in determining the economics of foraging at a variety of scales (Schneider 1991). As we develop predictive models of how birds should use the marine environment, it may be possible to couple these models with measurements of the energy budgets of the birds. When we can relate foraging patterns to costs that may eventually be related to reproductive success and survival, we will not only be able to describe the linkages of birds to the marine environment, but also to interpret the various behavior patterns in terms of natural selection.

Acknowledgements. - I thank P. Hunt and D. Schneider for helpful comments on an earlier version of the manuscript. I thank the sponsors of Pro Mare for their support of my participation in their program and this symposium and the U.S. National Science Foundation, Division of Polar Programs, for support of research in the Arctic and Antarctic.

\section{References}

Abrams, R. W. \& Lutjeharms, J. R. E. 1988: Relationships between seabirds and meso-scale hydrographic features in the Agulhas Current Retroflection region. Pp. 991-996 in Oulette, H. (ed.): Proc. XIX Internat. Ornithological Congress. Univ. Ottawa Press, Ottawa.

Ainley, D. G. 1977: Feeding methods in seabirds: A comparison of polar and tropical nesting communities in the eastern Pacific Ocean. Pp. 669-685 in Lano, G. A. (ed.): Adaptations within Antarctic ecosystems. Smithsonian Institution. Washington, D.C.

Ainley, D. G. \& Boekelheide, R. H. 1983: An ecological comparison of oceanic seabird communities in the south Pacific Ocean. Studies in Avian Biology 8, 2-23.

Ainley, D. G. \& DeMaster, D. P. 1990: The upper trophic levels in polar ecosystems. Pp. 599-630 in Smith. W. E. (ed.): Polar Oceanography. Academic Press, Orlando. 
Ainley. D. G. . O'Connor, E. F. \& Boekelheide, R. H. 1984: The marine ecology of birds in the Ross Sea. Antarctic. Ornithological Monographs $32.97 \mathrm{pp}$

Alexander, V. \& Niebauer, H. J. 1981: Oceanography of the eastern Bering Sea ice-edge zone in spring. Limnol. Oceanogr. 26, 1111-1125

Barstow, S. F. 1983: The ecology of Langmuir circulation: a review. Mar. Environ. Res. 9, 211-236.

Belopol'skii, L. O. 1957: Ecology of sea colony birds of the Barents Sea. Israel Program for Scientific Translations (1981), Jerusalem, Israel

Birkhead, T. R. \& Furness, R. W. 1985: Regulation of scabird populations. Pp. 145-167 in Sibley. R. M. \& Smith. R. H. (eds.): Behavioral ecology: ecological consequences of adapive behavior. Blackwell, London.

Blomqvist, S. \& Elander. M. 1981: Sabine's Gull (Xema sabini), Ross's Gull (Rhodostethia rosea) and Ivory Gull (Pagophila eburnea). Gulls in the Arctic: A review. Arctic 34, 122-132.

Blomqvist, S. \& Peterz, M. 1984: Cyclones and pelagic seabird movements. Mar. Ecol. Prog. Ser. 20, 85-92.

Bradstreet, M. S. W. 1979: Thick-billed Murres and black guillemots in the Barrow Strait area. N.W.T.. during spring: distribution and habitat use. Can. J. Zool. 58, 2120-2140.

Bradstreet. M. S. W. 1982: Occurrence, habitat use and behavior of seabirds. marine mammals and Arctic cod at the Pond Inlet ice edge. Arctic 35, 28-40

Bradstreet. M. S. W. 1988: Importance of ice edges to HighArctic seabirds. Pp. 997-1000 in Oullette. H. (ed.): Proc. XIX Internat. Ornithological Congress. Univ. Ottawa Press. Ottawa.

Briggs, K. T. Ainley. R. G.. Spear, L. B., Adams, P. B. \& Smith, S. E. 1988: Feeding of two alcids at central California upwellings. Pp. 982-990 in Oulette, H. (ed.): Proc. $X I X$ Internat. Ornithol. Congress Univ. Ottawa Press, Ottawa.

Brown, R. G. B. 1980: Seabirds as marine animals. Pp. 1-39. in Burger, J. Olla, B. L. \& Winn. H. E. (eds.): Behavior of Marine Animals, Vol. 4. Plenum, New York

Brown, R. G. B. 1989: Seabirds and the Arctic marine environment. Pp. 179-200 in Rey. L. \& Alexander. K. (eds.): Proc, 6th Conf. Comité. Arctique Internat, 13-15 May 1985. Brill, New York.

Brown, R. G. B. \& Gaskin, D. E. 1988: The pelagic ecology of the grey and red-necked phalaropes Phalaropus fulicarius and $P$. lobatus in the Bay of Fundy, eastern Canada. Ibis 130. 234-250.

Buckley, J. R., Gammelsrød, T., Johannssen, J. A.. Johannssen, O. M. \& Røcd, L. P. 1979: Upwelling: Oceanic structure at the edge of the Arctic ice pack in winter. Science 203, 165-167.

Coyle, K. O. \& Cooney, R. T. 1988: Estimating carbon flux to pelagic grazers in the ice-edge zone of the eastern Bering Sea. Mar. Biol. 98, 299-306.

Croxall. J. P. 1984: Seabirds. Pp. 533-616 in R. M. Laws (ed.): Antarctic Ecol. Vol. 2. Academic Press, London.

Croxall. J. P. 1987: Seabirds: feeding biology and role in marine ecosystems. Cambridge Univ. Press, Cambridge.

Divoky. G. 1979: Sea ice as a factor in seabird distribution and ecology in the Beaufort. Chukchi and Bering Seas. Pp. 9-18 in Bartoneck. J. C. \& Nettleship. D. N. (eds.): Conservation of Marine Birds of Northern North America. U.S. Fish and Wildife Services Research Report 11.

Dunbar. M. J. 1981: Physical causes and biological significance of polynyas and other open water in sea ice. Pp. 29-43 in Stirling. 1. \& Cleator. H. (eds.): Polynyas in the Canadian Arctic. Canadian Wildlife Service Occasional Paper 45
Everson. 1. 1983: Variations in vertical distribution and density of krill swarms in the vicinity of South Georgia. Memoirs National Institute for Polar Research, Tokyo. Special Issue 27. 84-92.

Fraser, W. R. \& Ainley, D. G. 1986: Ice edges and seabird occurrence in Antarctica. BioScience 36, 258-263.

Furness, R. W. \& Birkhead, T. R. 1984: Seabird colony distributions suggest competition for food supplies during the breeding season. Nature $311,655-656$.

Gaston, A. J.. Chapdelaine. G. \& Noble. A. G. 1983: The growth of thick-billed murre chicks at colonies in Hudson Strait: Inter- and intra-colony variation. Can. J. Zool. 6I. 2465-2475

Griffiths. A. M.. Siegfried, W. R. \& Abrams, R. W. 1982: Ecological structure of a pelagic seabird community in the Southern Ocean. Polar Biol. 1, $39-46$.

Gulliksen, B. \& Lønne, O. J. 1989. Distribution, abundance. and ecological importance of marine sympagic fauna in the Arctic. Rapp. P.-v. Réun. Cons. Int. Explor. Mer 188, 133138.

Gulliksen, B. \& Lonne, O. J. 1991: Sca ice macrofauna in the Antarctic and the Arctic. J. Mar. Syst. 2, 53-61.

Hamner, W. M. \& Schneider, D. C. 1986: Regularly spaced rows of medusae in the Bering Sea: role of Langmuir circulation. Limnol. Oceanogr. 31, 171-177.

Haney, J. C. 1990: Winter habitat of common loons on the continental shelf of the southeastern United States. Wilson Bulletin 102, 253-263.

Haney. J. C. \& Stone, A. E. 1988: Seabird foraging factors and water clarity: are plunge divers really in the clear? Mar. Ecol. Prog. Ser. 49, 1-9.

Harrington, B. A.. Schreiber, R. W. \& Woolfenden, B. 1972 The distribution of the male and female Magnificent Frigatebirds, Fregata magnificens, along the gulf coast of Florida. Amer. Birds 26, 927-931.

Harrison. C. S. 1979: The association of marine birds and feeding grey whales. Condor 81, 93-95.

Haury, L. R., McGowen, J. A. \& Wiebe, P. H. 1978: Patterns and processes in the time-space scales of plankton distributions. Pp. 277-327 in Steele, J. H. (ed.): Spatial pattern in plankion communities. Plenum Press, New York.

Heinemann, D., Hunt, G. \& Everson, I. 1989: Relationships between the distributions of marine avian predators and their prey, Euphausia superba, in Bransfield Strait and Southern Drake Passage, Antarctica. Mar. Ecol. Prog. Ser. $58,3-16$

Hunt. G. L. 1990: The pelagic distribution of marine birds in a heterogeneous environment. Polar Research 8, 43-54.

Hunt. G. L. 1991: Marine ecology of seabirds in polar oceans. Amer. Zool. 31, 131-142.

Hunt. G. L. \& Harrison, N. M. 1990: Foraging habitat and prey taken by Least Auklets at King Island, Alaska. Mor. Ecol. Prog. Ser. 65, 141-150.

Hunt, G. L. \& Nettleship, D. N. 1988: Seabirds of high-latitude northern and southern environments. Pp. 1145-1155 in Oulette, H. (ed.): Proc. XIX Internat. Ornithological Congress. Univ. Ottawa Press. Ottawa.

Hunt, G. L. \& Schneider, D. C. 1987: Scale-dependent processes in physical and biological environment of marine birds. Pp. 7-41 in Croxall, J. P. (ed.): Seabirds: feeding biology and role in marine ecosystems. Cambridge Univ. Prcss, Cambridge.

Hunt. G. L.. Eppley, Z. A. \& Drury, W. H. 1981a: Breeding distribution and reproductive biology of marine birds in the eastern Bering Sea. Pp. 649-688 in Hood. D. W. \& Calder, 
J. A. (eds.): The eastern Bering Sea shelf oceanography and resources, Vol. 2. OMPA/NOAA, Washington, D,C.

Hunt, G. L., Eppley, Z. A. \& Schneider, D. C. 1986: Reproductive performance of seabirds: The importance of population and colony size. Auk 103, 305-317.

Hunt, G. L., Gould, P. J., Forsell, D. J. \& Peterson, H. 1981b; Pelagic distribution of marine birds in the eastern Bering Sea Pp. 689-718 in Hood, D. W. \& Calder, J. A. (eds.): The eastern Bering Sea shelf oceanography and resources. OMPA/ NOAA. Washington, D.C

Hunt, G. L., Harrison, N. M. \& Cooney, R. T. 1990a. The influence of hydrographic structure and prey abundance on foraging of Least Auklets. Studies in Avian Biol. 14, 7-22.

Hunt, G. L., Heinemann, D., Veit, R. R., Heywood, R. B. \& Everson, 1. 1990b: The distribution, abundance and community structure of marine birds in southern Drake Passage and Bransfield Strait, Antarctica. Cont. Shelf Res. 10, 243257.

Iverson, R. H., Whitledge, T. E. \& Goering, J. J. 1979: Finestructure of chlorophyll and nitrate in the southeastern Bering Sea shelf break front. Nature 281, 664-666.

Johannes, R. E. 1981: Words of the Lagoon. Univ. California Press, Berkeley. 245 pp.

Jouventin, P. \& Weimerskirch, H. 1990: Satellite tracking of Wandering Albatross. Nature 343, 746-748.

Kinder, T. H., Hunt, G. L., Schneider, D. C. \& Schumacker, J. D. 1983: Correlation between seabirds and oceanic fronts around the Pribilof Islands, Alaska. Estuar. Coast. Shelf Sci. 16. 309-319.

Manikowski, S. 1975: The effects of weather on the distribution of kittiwakes and fulmars in the North Atlantic. Acta Zoolica Cracoviensia 13, 489-498.

Mehlum, F. 1989: Summer distribution of seabirds in northern Greenland and Barents Seas. Norsk. Polarinst. Skr. 19I. 56 pp.

Miller, D. G. M. \& Hampton, I. 1989; Krill aggregation characteristics: spatial distribution patterns from hydroacoustic observations. Polar Biol. 10, 125-134.

Nerini, M. 1984: A review of grey whale feeding ecology. Pp. 423-450 in Jones, M. L., Swartz, S. L. \& Leatherwood, S (eds.): The grey whale Eschrichtius robustus. Academic Press, Orlando.

Niebauer, H. J. \& Alexander, V. 1985: Oceanographic frontal structure and biological production at an ice edge. Cont. Shelf Res. 4, 367-388.

Obst, B. S. 1985: Densities of Antarctic seabirds at sea and the presence of the krill Euphausia superba. Auk 102, 540-549.

Obst, B. S. \& Hunt, G. L. 1990: Foraging behavior of marine birds at grey whale mud plumes in the Bering Sea. Auk 107, 678-688

Owen, R. W, 1966: Small-scale horizontal vortices in the surface layer of the sea. J. Mar. Res. 24, 55-66.

Pingree, R. D., Forster, G. R. \& Harrison, G. K. 1974: Turbulent convergent tidal fronts, J. Mar. Biol. Ass. U.K. 54 , $469-479$.

SCAR. 1985: Report on the FIBEX seabird data workshop. BIOMASS Report Series 44.

Schneider, D. 1982: Fronts and seabird aggregations in the southeastern Bering Sea. Mar. Ecol. Prog. Ser. 10, 101-103.
Schneider, D. 1991: The role of fluid dynamics in the ecology of marine birds. Oceanogr. Mar. Biol. Ann. Rev. 29, 487521.

Schneider, D. C. Harrison, N. M. \& Hunt, G. L. 1987: Variation in the occurrence of marine birds at fronts in the Bering Sea. Estuarine, Coastal and Shelf Science 25, 241-257.

Schneider, D. C., Harrison, N. M. \& Hunt, G. L. 1990: Seabird diet at a front near the Pribilof Islands, Alaska. Studies in Avian Biology 14, 61-66.

Schneider, D. C., Hunt, G. L. \& Harrison, N. M. 1986: Mass and energy transfer to seabirds in the southeastern Bering Sea. Cont. Shelf Res. 5, 241-257.

Simard, Y., de Ladurantage, R. \& Therriault, R. C. 1986: Aggregation of euphauslids along a coastal shelf in an upwelling environment. Mar. Ecol. Prog. Ser. 32, 203-215.

Safina, C. \& Burger, J. 1985: Common Tern foraging: seasonal trends in prey fish densities and competition with Bluefish. Ecology 66, 1457-1463.

Safina, C. \& Burger, J. 1988: Ecological dynamics among prey fish, Bluefish, and foraging Common Terns in an Atlantic coastal system. Pp. 95-173 in Burger, J. (ed.): Seabirds and other marine vertebrates. Columbia Univ. Press, New York.

Shuntov, V. P. 1961: Migrations and distribution of sea birds in the southeastern part of the Bering Sea in the springsummer time (in Russian, English summary). Zool. $\mathrm{Zh} .40$, 1058-1069.

Smith, W. O. 1987: Phytoplankton dynamics in marginal ice zones. Oceanogr. Mar. Biol. Ann. Rev. 25, 11-38.

Smith, W. O. \& Nelson, D. M. 1986: Importance of ice edge phytoplankton production in the Southern Ocean. BioScience 36, 251-257.

Springer, A. M., Murphy, E. C., Roseneau, D. G., McRoy, C. P. \& Cooper, B. A. 1987: The paradox of pelagic food webs in the northern Bering sea. I. Seabird food habits. Cont. Shelf Res. 7, 895-911.

Squibb, R. C. \& Hunt, G. L. 1983: A comparison of nestingledges used by seabirds on St. George Island. Ecology 64, $727-734$

Stavn, R. H. 1971: The horizontal-vertical distribution hypothesis: Langmuir circulations and Daphnia distributions. Limnol. Oceanogr. 16, 453-466.

Stirling, I. 1980: The biological importance of polynyas in the 'Canadian Arctic. Arctic 33, 303-315.

Uda, M. 1938: Researches on 'Siome' or current rip in the seas and oceans. Geophys. Mag. 11, 307-372.

Veit, R. R. 1985: Long-tailed Jaegers wintering along the Falkland current. Amer. Birds 39, 873-878.

Veit, R. R. 1988: Spatial dispersion patterns of Antarctic seabirds. Ph.D. Thesis, University of California. Irvine.

Veit, R. R. \& Hunt, G. L. 1991: Broadscale density and aggregation of pelagic birds from a circumnavigational survey of the Antarctic Ocean. Auk 108,790-800.

Vermeer, K., Szabo, I. \& Greisman, P. 1987: The relationship between plankton-feeding Bonaparte's and Mew Gulls and tidal upwelling at Active Pass, British Columbia. J. Plankton Res. 9, 483-501.

Williams, A. J. 1974: Site preferences and interspecific competition among guillemots Uria aalge (L.) and Uria lomira (L.) on Bear Island. Ornis Scandinavia 5, 113-121. 
